\title{
Stubble Burning and its Impact on Air Quality in Delhi NCT: A Case Study
}

\author{
Geeta Singh $^{1}$, Amit Kumar ${ }^{2}$, Deepanshu Vaid ${ }^{3}$, Prashant Sharma ${ }^{4}$ \\ Department of Environmental Engineering, Delhi Technological University, \\ Delhi-110042, India

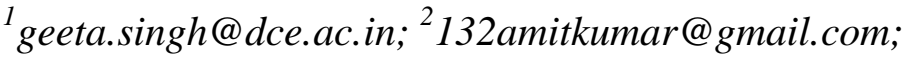 \\ 33eepanshuvaid_2k17en13@dtu.ac.in; ${ }^{4}$ prashantsharma_2k18en522@dtu.ac.in
}

\begin{abstract}
Stubble burning is now considered to be one of the major activity affecting the air quality because it is one of the major source of aerosol as well as gaseous pollution. There are two main reasons for biomass burning, first one is that there is a very short window of time between the harvesting and the wheat sowing of the wheat.Second being, removing the paddy residue that has remained on the field is a time-consuming job. The time period from harvesting to sowing being very low and the labor is either very expensive or unavailable this leads to the only easiest option that the farmer has i.e. burning the residue right on the field after harvest so that the farmers can quickly prepare the land for the next sowing. This method it very cheap and takes less time that's why farmers use this method. For this specific reason with the onset of winter stubble fires becomes rampant in north India. Stubble burning emissions contain toxic chemicals which causes respiratory problems as well as diseases. The paper aims to examine the environmental impacts associated with stubble burning over NCT of Delhi. The paper performs both qualitative and quantitative analysis on the statistical data pertaining to crop burning. The monthly variation for particulate matter (PM10 and PM2.5) and trace gases (NOx, CO, and SO2) during the stubble burning period (Sep-Nov) has also been studied and analyzed for 5 years (2015-19) and a noticeable increase in pollutant levels.
\end{abstract}

Keywords:Stubble, Burning, Pollutants, Emissions, NCT of Delhi, Air pollution, Aerosol, Smog

\section{Introduction}

Stubble burning has been known a significant jeopardy exceptional amount of pollution in the atmosphere as well deteriorates the soil. One of the major reasons of deterioration of air qualitythat happens annually from October to November,in the capital city of Delhi is due to stubble burning that happen in the neighboring states. (NITI Aayog, 2018). Stubble burning is defined as a process of removal of paddy crop residue from the field after harvesting for sowing the next crop i.e. wheat. Mainly 'combine harvesting' method is applied. Combines are machines that harvest as well as thresh, that means it separates the grain and clean it together. But the problem in this method is that it leaves stubble behind as it doesn't cut close to the ground. These residues put a burden on farmers as it is not useful to them and there is very less time available (20-25 days) for sowing of the next crop that puts a lot of pressure on the farmers, so for this specific reason the only easiest way available to them is to burn the residues right on the field.

Crop remainsburning is one of the major sourcecontributors of air pollution and deteriorating the air quality,just after industrial and vehicular emissions.According to a survey, humans are responsible for about $90 \%$ of stubble burning, with natural fires 
adding a negligible proportion of the overall amount of vegetation burnt (Mittal et al., 2009)

According to different studies, the residues of rice and wheat crops are major contributors to the total stubble burned in India.Garg et al. conducted a report in 2008 and published their results in the Indian Journal of Air Pollution Control, estimating that rice and wheat stubble residue contributed $36 \%$ and $41 \%$ of total stubble residue, respectively, in the year 2000, while Punjab contributed $11 \%$ and $36 \%$ of total burnt rice and wheat stubble, respectively. Mandal et al. (2004) calculated the total amount of crop residue produced in India and discovered that wheat residue accounts for about $27 \%$ and rice residue for about $51 \%$ of the total $350106 \mathrm{~kg}$ per year.Stubble burning is a common practice in many developing countries, particularly in Asia, for burning excess crop residue (Gadde et al., 2009, Mendoza et al., 2016). Burning the residue on the field creates a lot environmental issues, but ploughing the millions of hectares of field residue within a short time requires expensive labor as new technical assistance. Stubble burning is an unregulated uncontrolled combustion process that releases carbon dioxide (CO2), carbon monoxide (CO), unburnt carbon (as well as traces of methane i.e. $\mathrm{CH} 4$ ), nitrogen oxides (NOx), and a relatively small volume of sulphur dioxide (SO2), non-methane hydrocarbons (NMHC), particulate matter (PM), and a few other gases into the environment.In 2015, almost one million died due atmospheric particulate matter (PM2.5) pollution in India (Guo et al., 2017).

Typically, for evaluating the air quality the concentration of six pollutants is measured namely: P.M2.5, P.M10, Sulphur Dioxide (SO2), Carbon Monoxide(CO), Nitrogen Dioxide (NO2).( U.S.E.P.A 2018). The main sources of primary air pollution in Delhi are vehicle pollution, coal-fired power stations, diesel engines, building and road dust emissions, biomass/stubble burning, natural fires, and fossil fuel combustion (Kumar et at., 2017; Pant et al 2015; Saxena et al., 2017; Sharma, Mandal et al., 2016; Villalobos et al., 2015). New Delhi has been identified as one of the most polluted cities in terms of particulate matter (PM), with a peak value of $350 \mathrm{~g} / \mathrm{m} 3$, which is 3.5 times higher than the allowable limit of $100 \mathrm{~g} / \mathrm{m} 3$ (WHO, 2016, NAAQS, 2009).

Crop burning have had a significant impact over Delhi's climate although in general air pollution from different sources contributes to the overall degradation of the climate but in recent years stubble burning pollution have consistently increased its share upto $40 \%$ of total air pollution. It has a major impact on climate and human health as it is one of the major source of atmospheric aerosol and trace gases emission (Vander werf et al., 2006; Kharol and Badrinath, 2006; Pandey et al., 2005).The Northern regions of India especially Delhi is highly affected by with aerosols that hit optimum levels due to stubble burning during April to May and October to November, that is carried out around the same time due to harvesting of wheat and rice (Vadrevu et al., 2011; Venkataraman et al., 2006; Gadde et al., 2009; Sharma et al., 2010; Mishra and Shibata, 2012). 


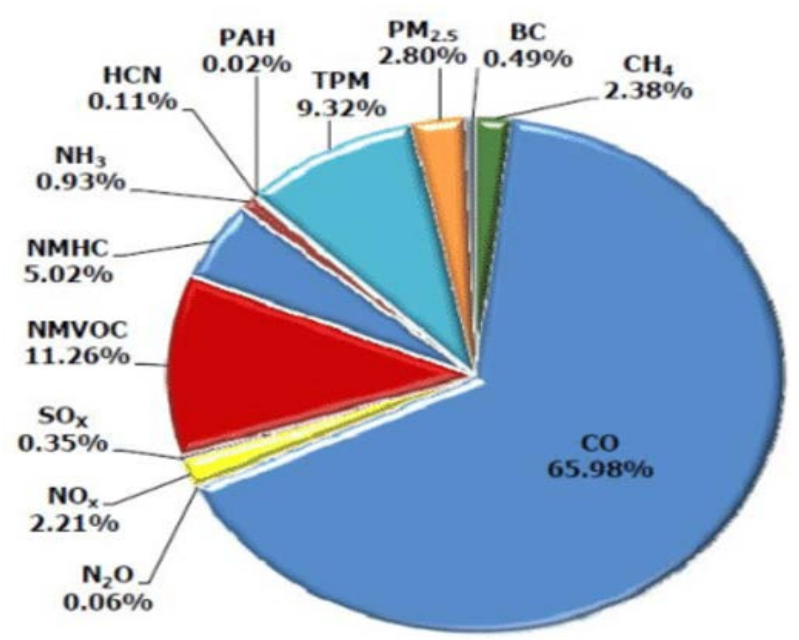

Figure 1. Major pollutants emitted during crop residue burning (Jain et al., 2014)

\section{Literature Review}

According to Jain et al. (2014), for the years 2008-09,the Inter-Governmental Panel on Climate Change (IPCC) National inventory planning recommendations were used to establish a state-by-state inventory of crop residue burner in India and the air contaminants released. In the same year, $620 \mathrm{Mt}$ was the total amount of residue generated out of which $15.9 \%$ was burnt. In which $40 \%$ of total residue was rice straw, $22 \%$ wheat straw, 20\% sugarcane trash. While burning of that residue, the emission was $8.57 \mathrm{Mt}$ for CO, 1.46 for NMVOC, $141.5 \mathrm{Mt}$ for CO2, 0.23Mt for NOx, 0.03Mt for SOx, 0.12Mt for NH3 and lastly 1.21Mt of Particular matter. For this Jain et al., (2014) used FBCR equation.

According to Gadde et al. (2009). Rice is a widely grown crop in Asia in which India's contribution is $21 \%$ of total production. For this study, Straw to Grain Ratio was used and for this the framework developed by the Intergovernmental Panel on Climate Change (IPCC) guidelines 2006 was used to measure the pollution caused by open field burning of rice straw .In comparison to general approaches in which default values are used to determine the volume of crop residues open burned and measure the resulting emissions using pollutant related emission factors for crop residues in general, the analysis found that such an approach significantly reduces uncertainties. Open burning of seed stubble, according to Gadde et al. (2009), emits dioxins such as polychlorinateddibenzo-pdioxins,polycyclicaromatichydrocarbons(PAHs), and polychlorinated dibenzofurans(PCDFs). These contaminants have toxicological properties and may cause cancer.

According to Gupta et al. (2004), burning 1 tonne of stubble produces $199 \mathrm{~kg}$ of fly ash, $1460 \mathrm{~kg}$ of CO2, $60 \mathrm{Kg}$ of $\mathrm{CO}, 2 \mathrm{Kg}$ of SO2 and $3 \mathrm{Kg}$ of particulate matters. Crop residue burning releases $91,4.1,0.6,0.1$, and 1.2 teragrams each year ( $\mathrm{Tg} / \mathrm{yr})$ of $\mathrm{CO} 2$, according to Yevich and Logan (2003). In Delhi, the PM released by burning crop residues is 17 times higher than that emitted by all other sources, such as car pollution and garbage burning.

\section{Methodology of the Study}




\subsection{Description of Study Area}

Delhi which is officially known as National Capital Territory (NCT of Delhi) is located at North Latitude from 28.24-28.53 degrees and East Longitude from 76.59-77.20 degrees .It is the largest city in terms of area in the country, with 24.90 percent of the total area classified as rural and 75.1 percent as urban. It is 51.9 kilometres long and 48.48 kilometres wide. Delhi is divided into 11 districts and 33 tehsils (sub-divisions). It is situated in seismic zone IV of INDIA and has a population of 16.8 million people. The climate in Delhi is semiarid, with exceptionally hot summers, moderate rainfall, and bitterly cold winters. Winter, which begins in December and ends in February, is the most critical season in Delhi due to the worst weather scenario. Cold, dry air and ground- based inversion with low wind conditions dominate this time, which occurs regularly and raises pollutant concentration (Anfossi et al., 1990).

Table 1: Specifications of Study Area (As per Census 2011, Economic survey of Delhi 2019-20)

\begin{tabular}{|c|c|}
\hline Specification & Area \\
\hline Total Area & $1483 \mathrm{~km}^{2}$ \\
\hline Population Density & $11,320 / \mathrm{km}^{2}$ \\
\hline Rural Area & $1113.65 / \mathrm{km}^{2}$ \\
\hline Urban area & $369.35 / \mathrm{km}^{2}$ \\
\hline Forest and Tree Cover Area & $324.44 \mathrm{~km}^{2}$ \\
\hline
\end{tabular}

Table 2: Brief description of monitoring stations chosen for the study

\begin{tabular}{|c|c|c|c|c|c|c|}
\hline State & $\begin{array}{c}\text { Name of } \\
\text { Monitoring } \\
\text { Station }\end{array}$ & $\begin{array}{l}\text { Monitoring } \\
\text { Station } \\
\text { Code }\end{array}$ & $\begin{array}{l}\text { Latitude/ } \\
\text { Longitude }\end{array}$ & $\begin{array}{c}\text { Type of } \\
\text { Monitoring } \\
\text { Station }\end{array}$ & $\begin{array}{c}\text { Managing } \\
\text { Agency }\end{array}$ & $\begin{array}{c}\text { Data } \\
\text { Coverage }\end{array}$ \\
\hline \multirow{5}{*}{ Delhi } & R K Puram & RKP & $\begin{array}{l}28.674045, \\
77.131023\end{array}$ & Residential & DPCC & $94.7 \%$ \\
\hline & $\begin{array}{l}\text { IGI Airport } \\
\text { (T3 } \\
\text { Terminal) }\end{array}$ & IGI & $\begin{array}{l}28.5551, \\
77.0844\end{array}$ & $\begin{array}{l}\text { Industrial \& } \\
\text { Commercial }\end{array}$ & $\overline{\mathrm{CPCB}}$ & $89.9 \%$ \\
\hline & $\begin{array}{l}\text { Punjabi } \\
\text { Bagh }\end{array}$ & PB & $\begin{array}{l}28.563262, \\
77.186937\end{array}$ & $\begin{array}{l}\text { Residential, } \\
\text { Industrial \& } \\
\text { Commercial }\end{array}$ & DPCC & $94 \%$ \\
\hline & $\begin{array}{l}\text { Mandir } \\
\text { Marg }\end{array}$ & MM & $\begin{array}{l}\text { 28.636429, } \\
77.201067\end{array}$ & $\begin{array}{l}\text { Residential } \\
\& \\
\text { Commercial }\end{array}$ & DPCC & $87.8 \%$ \\
\hline & AnandVihar & $\mathrm{AV}$ & $\begin{array}{l}28.6502, \\
77.3027\end{array}$ & $\begin{array}{l}\text { Residential, } \\
\text { Commercial } \\
\text { \& Industrial }\end{array}$ & DPCC & $86.2 \%$ \\
\hline
\end{tabular}




\subsection{Site Selection}

For the present study NCT of Delhi has been selected as the study area for the analysis of effect of stubble burning. Among all the states getting affected by stubble burning, the case of NCT of Delhi is highly unique, for three primarily reasons:

- The NCT of Delhi is highly urbanized and doesn't have any major portion of its land devoted for entirely farming yet it gets highly affected and polluted during crop burning season, as compared to its other surrounding states

- Geography- Himalayas act like a barrier which directs the smoke to Delhi.

- Weather: During the winter, cool mountain air floods down from the Himalayas into Delhi, riding under a blanket of warm lowland air that forms a bubble over the capital, trapping dust on the ground. When stubble fire smoke reaches Delhi, it combines with urban pollution, creating a poisonous smog that hangs over the city.

\subsection{Parameters for Analysis}

To understand the impact of emitted pollutants released from stubble burning over the study area parameters are chosen viz Effect on air quality \& Effect on climate. Category centric analysis and interpretation, has been than carried out for the understanding of the impact of stubble burning emitted pollutants over these specific parameters.For the study, varied forms of data have been collected from appropriate sources. The data collection and manipulation is based upon the parameter of the study in consideration.

\subsubsection{Effect on Air Quality}

- Pollutants Analyzed: PM2.5, PM10, CO, NOx, and SO2 are the study's criteria for analysing the impact of stubble burning on the NCT of Delhi. All of these toxins have a clear association with stubble burning emissions, and they are also a significant influencer among all stubble burning contributors.

- Monitoring Stations: Five monitoring stations viz: RK Puram, Punjabi Bagh, Mandir Marg, IGI Airport (T3 Terminal), AnandVihar. These stations were selected because they are spread over many zones (North, South, East, West, and Central) and therefore have a diverse set of data for study and also due to availability of historical air pollution data. .

- Collection of information regarding the concentration of the respective pollutants for all of the 5 monitoring stations for three months period (From 15 September15 November) for the study period from 2015-2019.

\subsubsection{Effect on Climate}

For the appropriate time frame, spatial distribution data for aerosol optical density (AOD) was obtained. By analysing the absorbed sunlight from the earth's atmosphere and surface, as well as released thermal radiation at thirty six wavelengths, the Moderate Resolution Imaging Spectrometer (MODIS) on board TERRA/AQUA satellites offer regular global knowledge on Earth's atmospheric aerosol properties. To do so we generated 5 AOD maps equally covering the months of October and November of each year from 2015 to 2019. 


\section{Result and Discussion}

Following points were observed during the evaluation of the impact of stubble burning for NCT of Delhi, over the study period:

1. The aerosol data for the targeted period of 2 months (15 Sep-15 Nov) taken successively for 5 year (2015-19) is as follows: 2015-0.88 AOD, 20160.93 AOD, 2017-0.76 AOD, 2018- 0.80 AOD, 2019- 0.96 AOD. Among the AOD values 1st and 2nd highest peaks were obtained for years 2019 and 2016 respectively. : Spatial distribution of AOD over India for a period of 5 years is shown Figure 3.
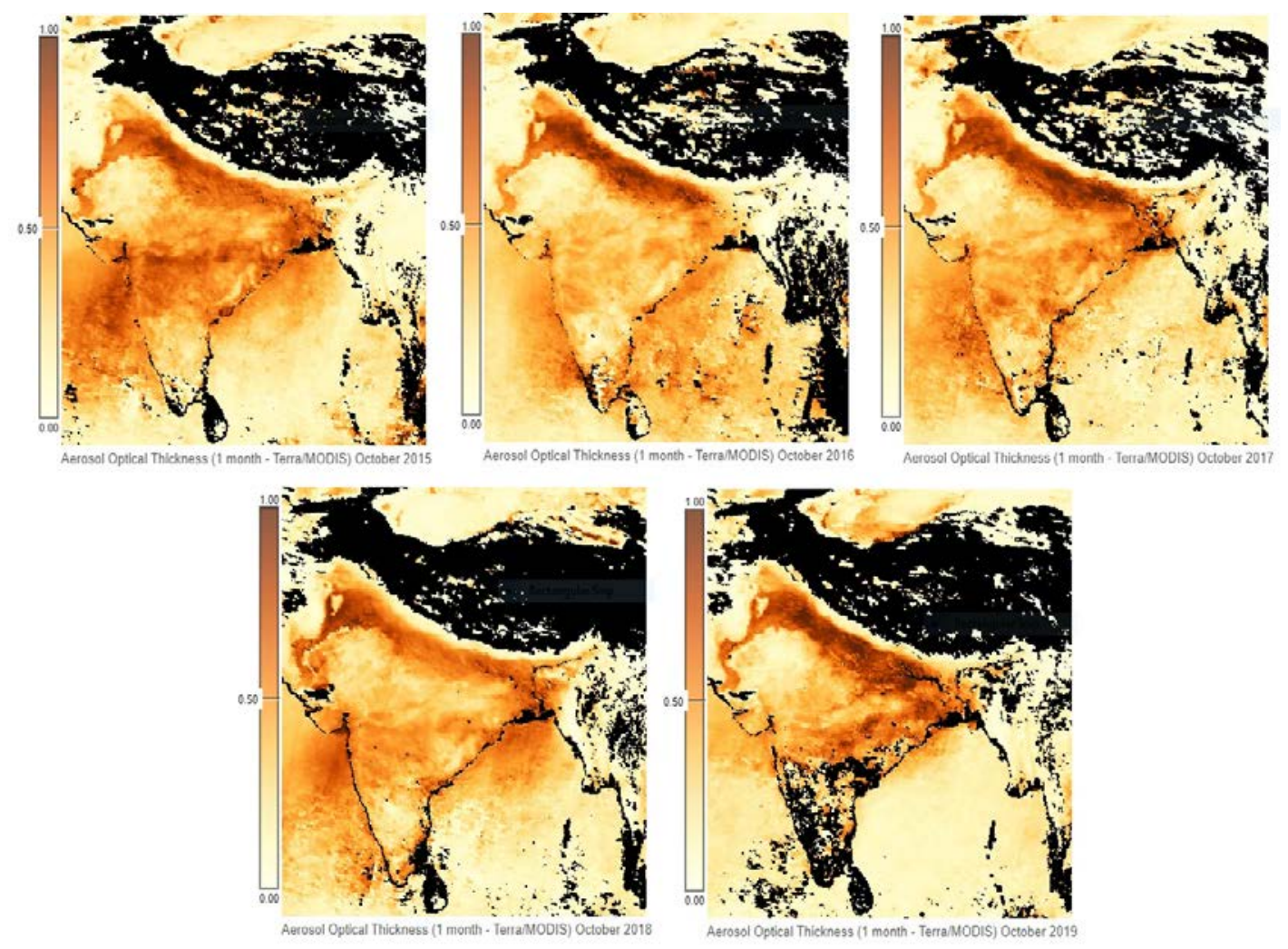

Figure 3: Spatial distribution of AOD over India for October-November (2015-2019)

2.Rapid urbanisation, increased localised fire emissions, and long-range transport of aerosols from the Indo-Gangetic Plane zone could all contribute to the highest peak aerosol loading over Delhi. Aerosols also act as cloud condensation nuclei, influencing cloud formation and rainfall, resulting in increased AOD loading.

3.The pollutants concentration data for pollutants: PM2.5, PM10, NOx, SO2, CO overserved for stubble burning period (15 Sep-15 Nov) for 5 years (2015-19) is shown in the Figure 4 . The years in which different pollutants under consideration obtained peaks are: PM2.5-2017(656.91 $\left.\mu \mathrm{g} / \mathrm{m}^{3}\right)$, PM10-2016(916.19 $\left.\mu \mathrm{g} / \mathrm{m}^{3}\right)$, CO-2017(4.35 mg/m $)$, Nox-2016(408.2 $\left.\mu / \mathrm{m}^{3}\right)$, So2-2016(77.55 $\left.\mu \mathrm{g} / \mathrm{m}^{3}\right)$. 

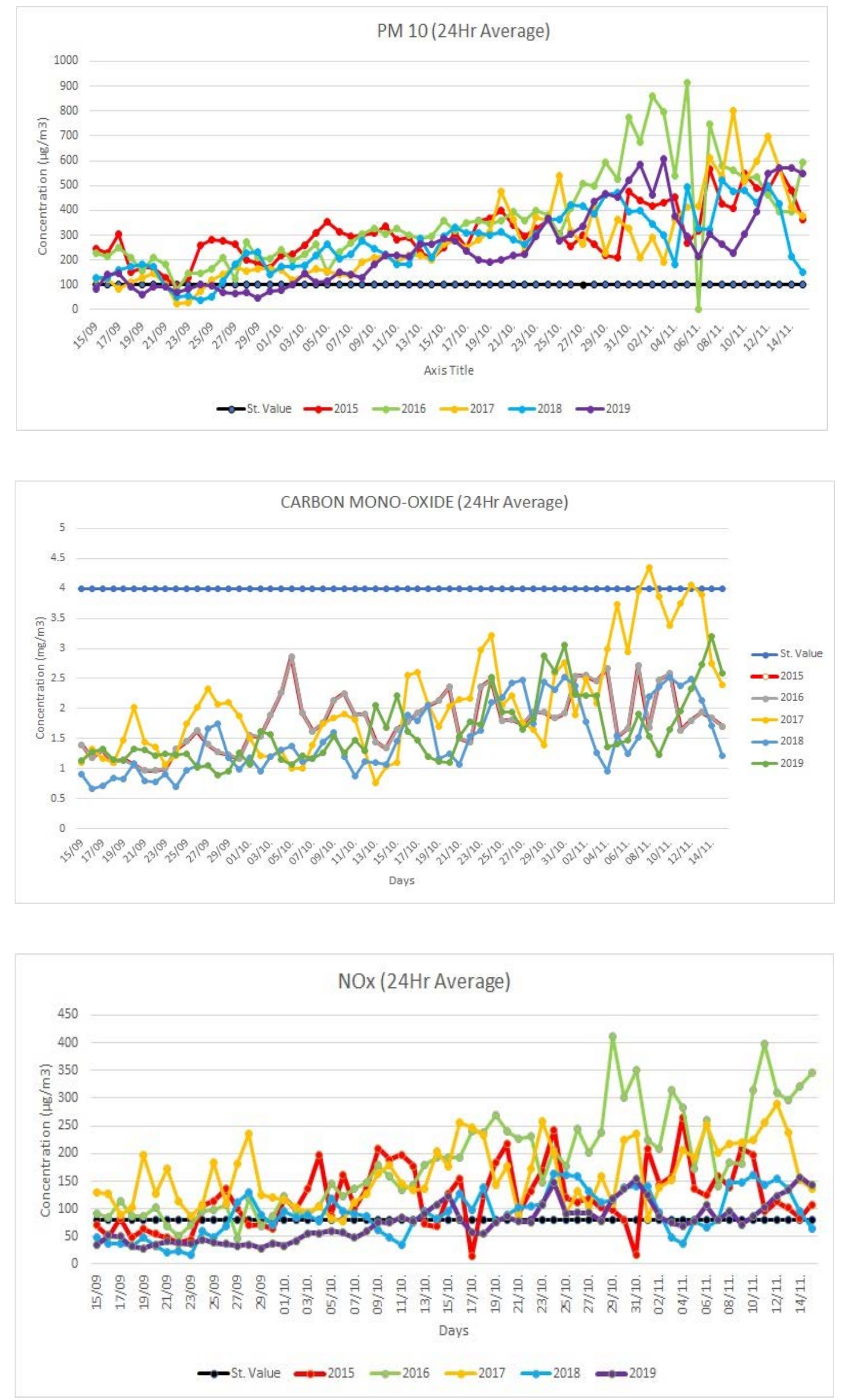

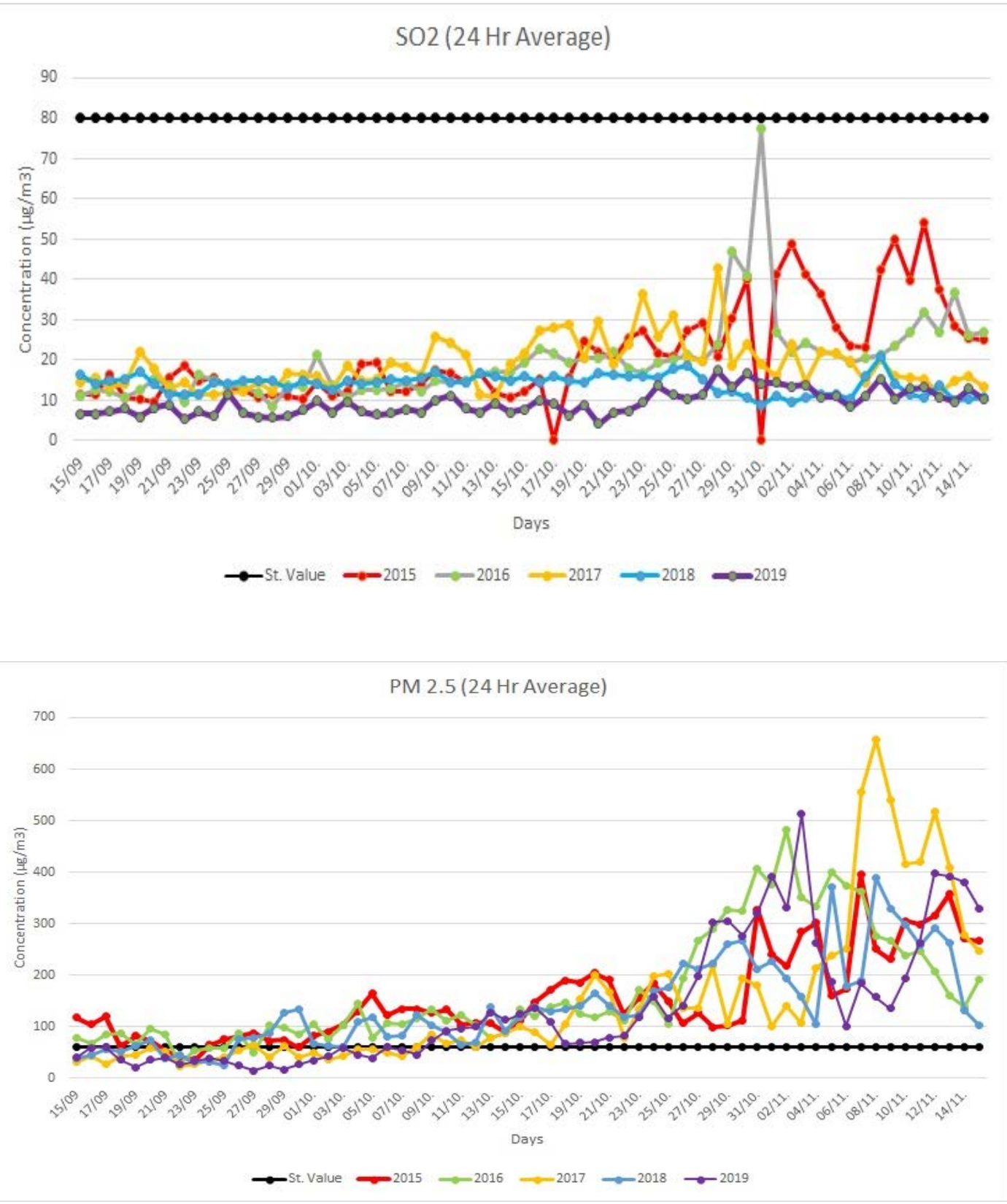

Figure 4. Time series variations of PM2.5, PM10, SO2, NO2 \& CO during the period (15 Sep- 15 Nov) for 5 years period from 2015-2019. The black lines indicates permissible limit for all the pollutants.

4. Every pollutant under consideration showed concentration level exceeding multiple times, that of prescribed limit by NAAQ. Except SO2 and CO. The concentration of pollutants during their peak and the amount of exceeding are as follows: PM2.5- 11x

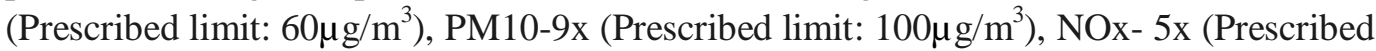
limit: $80 \mu \mathrm{g} / \mathrm{m}^{3}$ ), CO-1x (Prescribed limit: 4mg/m³), SO2-1x (Prescribed limit: $100 \mu \mathrm{g} / \mathrm{m}^{3}$ )

5. The $\mathrm{CO}$ and $\mathrm{SO} 2$ showed concentration almost the same as prescribed as the safe limit even at the time of their peak concentration through the period of observation. During the rest of the study period they showed even lower and safer concentration levels then their prescribed levels. The reason can be simply as because the percentage of SO2 and CO concentration in the total stubble burning emission is 0.2 and $6 \%$ respectively. Since the 
overall contribution is very minute in the total stubble burning emissions, so their concentration remain quite less during our study period. A considerable intra-seasonal and inter-annual variation of stubble burning has been observed over the region. The 5 year (2015-2019) data of active VIRS fire count reveals an increase in the fire count per year. Time variation of PM2.5 and VIRS count shown in Figure 5.

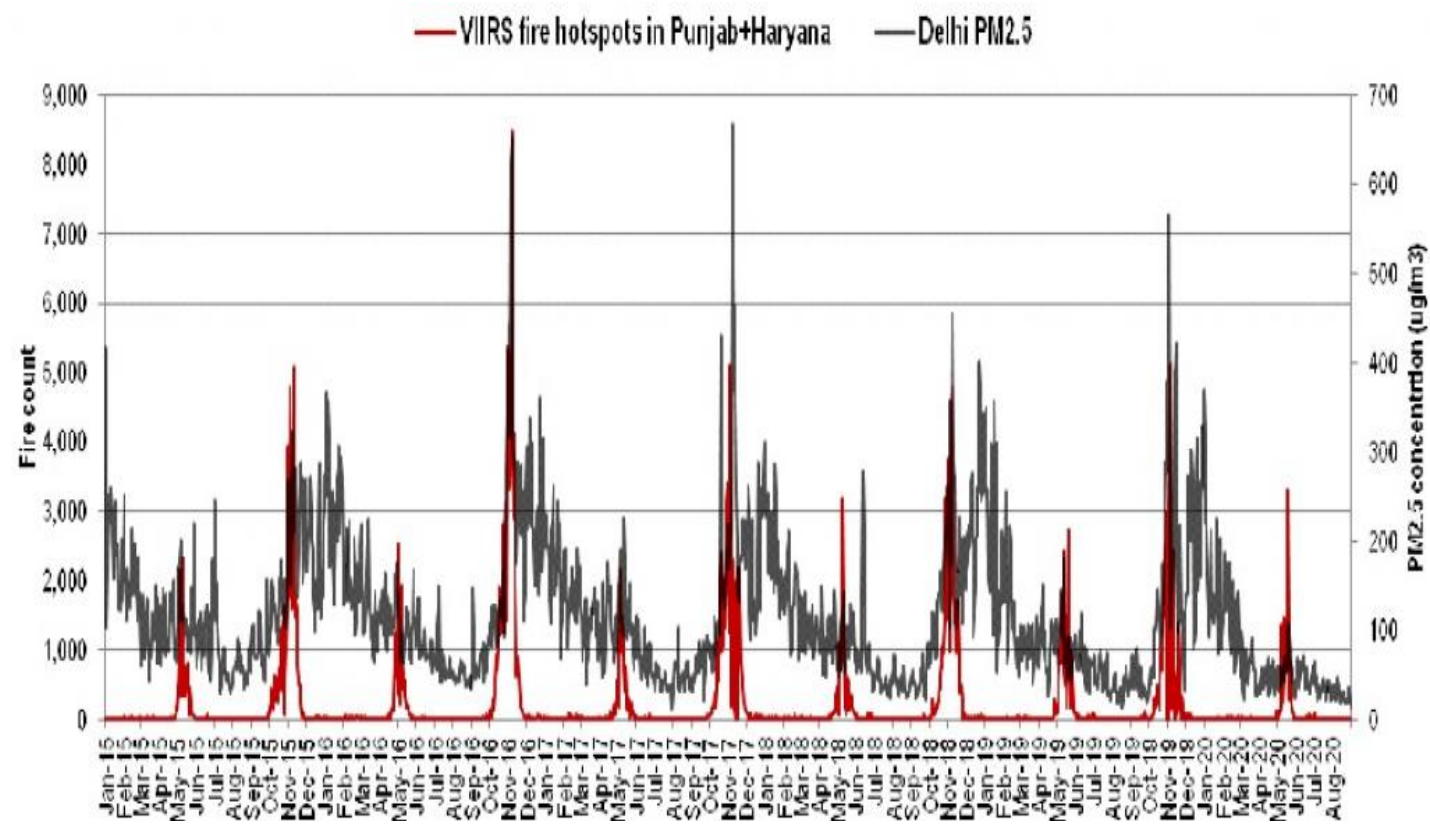

Figure5. The time series variations of PM2.5 and VIRS fire count from 2015-2020

\section{Conclusions}

The present study in consideration caters to an idea of getting both qualitative and quantitative impact of pollutants emissions from stubble burning over NCT Delhi. It can be clearly estimated that problems and challenges pertaining to air pollution are entirely different in winters (stubble burning period) than comparatively when crop burning isn't done (summers). Since due to characteristic geography and the consequent environment of Delhi forces the carrier winds to drive away the stubble generated pollution towards Delhi from the fields of Punjab and Haryana in winters which get intense in the months of September-November. This accumulated stubble pollution combined with pollutants from other sources creates AOD which further hinders in visibility and affects the overall climate environment over Delhi. A specific example in this regards can be 'The Great Smog' event of 2016 of Delhi. This five years study also shows that the different pollutants under consideration show concentration levels manifolds higher than the prescribed limit by NAAQ standards, exception being SO2, CO. The AOD data for the study period (2015-19) correlates well with the VIRS Fire data for the Haryana-Punjab area for the same five-year period, showing that not only did the region experience intense stubble burning, but it also had a direct link to increased emissions in Delhi during the winter months.Also a long term impact over health's of citizens of Delhi shows the same indications that higher pollution levels specifically in winters(stubble burning period) is affecting their respiratory and overall health. Rise in the cases of respiratory ailments related patients and death in MCCD hospitals give an indirect measure of this influence. As a result, there is an immediate need to upgrade the current equipment used in crop 
processing to combat the emissions caused by crop burning. In addition, the government can have incentives for the new equipment, which will help produce less waste when it comes to stubble-producing crops.

\section{References:}

Anfossi, D., Brusasca, G., \&Tinarelli, G. (1990). Simulation of atmospheric diffusion in low windspeed meandering conditions by a Monte Carlo dispersion model. IlNuovoCimento C, 13(6), 995-1006.

Gadde, B., Bonnet, S., Menke, C., \&Garivait, S. (2009). Air pollutant emissions from rice straw open field burning in India, Thailand and the Philippines. Environmental Pollution, 157(5), 1554-1558.

Garg, S. C. (2008). Trace gases emission from field burning of crop residues. Indian Journal of Air Pollution, 8, 76-86.

Guo, H., Kota, S. H., Sahu, S. K., Hu, J., Ying, Q., Gao, A., \& Zhang, H. (2017). Source apportionment of PM2.5 in North India using source-oriented air quality models. Environmental Pollution, 231, 426-436.

Gupta, P. K., Sahai, S., Singh, N., Dixit, C. K., Singh, D.P., Sharma, C., \& Garg, S. C. (2004). Residue burning in rice-wheat cropping system: Causes and implications. Current science, 1713-1717.

Jain, N., Bhatia, A., \& Pathak, H. (2014). Emission of air pollutants from crop residue burning in India. Aerosol and Air Quality Research, 14(1), 422-430.

Kharol, S. K., \&Badarinath, K. V. S. (2006). Impact of biomass burning on aerosol properties over tropical urban region of Hyderabad, India. Geophysical Research Letters, 33(20).

Kumar, B., Tirkey, N., \& Kumar, S. (2017). Anti-nutrient in fodders: a review. Chemical Science Review and Letters, 6, 2513-2519.

Mandal, K. G., Misra, A. K., Hati, K. M., Bandyopadhyay, K. K., Ghosh, P. K., \&Mohanty, M. (2004). Rice residue-management options and effects on soil properties and crop productivity. Journal of Food Agriculture and Environment, 2, 224-231.

Mendoza, T. C., \& Mendoza, B. C. (2016). A review of sustainability challenges of biomass for energy, focus in the Philippines. Agric. Technol, 12, 281-310.

Mishra, A. K., \& Shibata, T. (2012). Synergistic analyses of optical and microphysical properties of agricultural crop residue burning aerosols over the Indo-Gangetic Basin (IGB). Atmospheric Environment, 57, 205-218.

Mittal, S. K., Singh, N., Agarwal, R., Awasthi, A., \& Gupta, P. K. (2009). Ambient air quality during wheat and rice crop stubble burning episodes in Patiala. Atmospheric Environment, 43(2), 238-244.

Pandey, J. S., Kumar, R., \&Devotta, S. (2005). Health risks of NO2, SPM and SO2 in Delhi (India). Atmospheric Environment, 39(36), 6868-6874.

Pant, P., Shukla, A., Kohl, S. D., Chow, J. C., Watson, J. G., \& Harrison, R. M. (2015). Characterization of ambient PM2.5 at a pollution hotspot in New Delhi, India and inference of sources. Atmospheric environment, 109, 178-189.

Saxena, M., Sharma, A., Sen, A., Saxena, P., Mandal, T. K., Sharma, S. K., \& Sharma, C. (2017). Water soluble inorganic species of PM10 and PM2.5 at an urban site of Delhi, India: seasonal variability and sources. Atmospheric Research, 184, 112-125.

Sharma, A. R., Kharol, S. K., Badarinath, K. V. S., \& Singh, D. (2010, February). Impact of agriculture crop residue burning on atmospheric aerosol loading - a study over Punjab State, India. In AnnalesGeophysicae(Vol. 28, No. 2, pp. 367-379).

Sharma, S. K., Mandal, T. K., Jain, S., Sharma, A., \&Saxena, M. (2016). Source apportionment of PM2.5 in Delhi, India using PMF model. Bulletin of environmental contamination and toxicology, 97(2), 286-293.

USEPA, 2018. Technical Assistance Document for the Reporting of Daily Air Quality - the Air Quality Index. (AQI).

Vadrevu, K. P., Ellicott, E., Badarinath, K. V. S., \&Vermote, E. (2011). Modis derived fire characteristics and aerosol optical depth variations during the agricultural residue burning season, north India. Environmental pollution, 159(6), 1560-1569. 
Van der Werf, G. R., Randerson, J. T., Giglio, L., Collatz, G. J., Kasibhatia, P. S., \& Arellano Jr, A. F. (2006). Interannual variability in global biomass burning emissions from 1997 to 2004. Atmospheric Chemistry and Physics, 6(11), 3423-3441.

Venkataraman, C., Habib, G., Kadamba, D., Shrivastava, M., Leon, J. F., Crouzille, B., \& Streets, D. G. (2006). Emissions from open biomass burning in India: Integrating the inventory approach with highresolution Moderate Resolution Imaging Spectroradiometer (MODIS) active-fire and land cover data. Global biogeochemical cycles, 20(2).

Villalobos, A. M., Amonov, M. O., Shafer, M. M., Devi, J. J., Gupta, T., Tripathi, S. N., \&Schauer, J. J. (2015). Source apportionment of carbonaceous fine particulate matter (PM2.5) in two contrasting cities across the Indo- Gangetic Plain. Atmospheric Pollution Research, 6(3), 398-405.

World Health Organization (2016). World Health Organization ambient air pollution: A global assessment of exposure and burden of disease.

Yevich, R., \& Logan, J. A. (2003). An assessment of biofuel use and burning of agricultural waste in the developing world. Global biogeochemical cycles, 17(4). 